\title{
LUT
}

University

\section{Sustainability and Knowledge Dynamics in Entrepreneurial Growth: Evidence from Internationalizing Finnish SMEs}

Torkkeli Lasse, Uzhegova Maria, Salojärvi Hanna, Saarenketo Sami

This is a Final draft

version of a publication

published by Emerald Publishing

in Sindakis, S.; Theodorou, P. (Eds.) Global Opportunities for Entrepreneurial Growth: Coopetition and Knowledge Dynamics within and across Firms

DOI: $10.1108 / 978-1-78714-501-620171026$

Copyright of the original publication: (c) Emerald Publishing 2018

Please cite the publication as follows:

Torkkeli, L., Uzhegova, M., Salojärvi, H., Saarenketo, S. (2017). Sustainability and Knowledge Dynamics in Entrepreneurial Growth: Evidence from Internationalizing Finnish SMEs. In:

Sindakis, S.; Theodorou, P. (Eds.) Global Opportunities for Entrepreneurial Growth: Coopetition and Knowledge Dynamics within and across Firms. Emerald Publishing. pp. 453-474. DOI: 10.1108/978-1-78714-501-620171026

This is a parallel published version of an original publication. This version can differ from the original published article. 


\section{Chapter 21}

\section{Sustainability and Knowledge Dynamics in Entrepreneurial Growth: Evidence from Internationalizing Finnish SMEs}

Lasse Torkkeli, Maria Uzhegova, Hanna Salojärvi, Sami Saarenketo

Cite as: Torkkeli, L., Uzhegova, M., Salojärvi, H. \& Saarenketo, S. (2018). Sustainability and Knowledge Dynamics in Entrepreneurial . Growth: Evidence from Internationalizing Finnish SMEs. In: Global Opportunities for Entrepreneurial Growth: Coopetition and Knowledge Dynamics within and across Firms. Sindakis, S. \& Theodorou, P. (Eds.). Emerald Group Publishing, pp. 453-474. DOI: https://doi.org/10.1108/978-1-78714-501-620171026

\section{Chapter 21}

\section{Sustainability and Knowledge Dynamics in Entrepreneurial Growth: Evidence from Internationalizing Finnish SMEs}

The impact of environmental sustainability and knowledge dynamics on entrepreneurial growth and internationalization could do with added research focus. However, the rising importance of corporate sustainability and social responsibility in global business and entrepreneurship increasingly requires that these interdependencies be assessed. We assess these dynamics empirically through both quantitative and qualitative analysis. With the former, we employ a cross-sectional sample of Finnish small- and medium-sized enterprises (SMEs) to illustrate the impact of learning orientation and environmental sustainability on their growth and internationalization. Specifically, we find that their impacts on entrepreneurial growth depend on the stage of their internationalization: Learning orientation predicts first foreign market entry among the enterprises, while environmental orientation predicts the subsequent performance among internationally operating enterprises. In addition, we find no moderation or mediation effects between learning orientation and sustainability, suggesting that their impacts are distinct 
from each other. We conclude by discussing these results and their implications on international entrepreneurial growth, and knowledge and sustainability dynamics in the entrepreneurial context.

Keywords: Entrepreneurial Growth, International Entrepreneurship, Sustainability, Organizational Knowledge, Learning Orientation

\section{$\underline{21.1 \text { Introduction }}$}

Small and medium-sized enterprises (SMEs) are crucial for growth of economies globally in general, as well as in the European Union in particular: For instance, when adhering to a common definition of SMEs as independent companies employing fewer than 250 people, according to the European Commission, $99.8 \%$ of all companies in the area are classified as SMEs. In the long term, the growth of these companies usually requires internationalization, which however presents challenges for SMEs due to their lack of resources and marketing knowledge needed in order to internationalize successfully (e.g. Burpitt \& Rondinelli, 1998; Knight \& Cavusgil, 2004). Thus, opportunities for entrepreneurial growth tend to be interlinked also with international, rather than merely domestic entrepreneurship.

International entrepreneurship in turn tends to be a process driven by learning: Being able to accumulate knowledge from foreign markets in order to facilitate entry to that market is the dynamic underlying the central models of internationalization, most notably the Uppsala-model (Johanson \&Wiedersheim-Paul 1977; Johanson \& Vahlne 1979; 1990). Moreover, for smaller enterprises seeking to internationalize rapidly, the importance of organizational learning is wellestablised (e.g., Autio et al., 2000; Pla-Barber \& Alegre, 2014). Indeed, organizational learning is one of the main determinants of how SMEs are able to engage in international and growth entrepreneurship successfully (e.g., Jones et al., 2011). However, less is known on the effect of learning culture in research literature. With learning culture, we refer here to the potential impact that learning as a strategic orientation of an SME - the extent of its learning orientation (Baker \& Noordewier, 1997; Baker \& Sinkula, 1999) - can have in facilitating recognition of international and global opportunities among enterprises.

Another strategic orientation whose impact on international growth of enterprises we know little of is environmental orientation, the extent of which determines how committed to corporate social responsibility and to preservation of the natural environment an enterprise is (Menguc \& Ozanne, 2005). Being environmentally oriented is increasingly both required from and beneficial 
to enterprises: the former through the fact that stakeholder increasingly expect acts of corporate environmentalism (Banerjee, 2002), and the latter due to rise of new industry sectors where environmentalism and corporate social responsibility are the basis of operations.

One of such newly arising industries is the cleantech sector, which entails products, services and processes in which their key characteristic is related to minimizing ecological impact and maximizing efficiency in order to emphasize responsibility in using natural resources (see Kachan \& Co., 2013). Indeed, companies particularly in the cleantech sector play a critical role both in solving environmental problems as well as drivers of sustainable growth. In spite of this, very little on the determinants of growth and seizing of international opportunities globally in cleantech companies is currently known.

In sum, then, there are gaps in literature in considering organizational learning in the context of SMEs seeking to grow through international markets specifically, as well as in outlining the impact of environmental orientation and sustainability on internationalization of SMEs in general, and on entrepreneurs and their enterprises operating in sectors emphasizing sustainability, such as cleantech.

This study thus seeks answers to these omissions, and extends prior research in two main ways. First, we are able to distinguish between the roles of two under-researched strategic orientations, learning orientation and environmental orientation, on internationalization outcomes and growth of SMEs. Second, by incorporating qualitative data, we further illustrate the specifics of these orientations and their manifestation in an industry sector where their importance is accentuated, by investigating a cleantech SME through a case study.

This study continues as follows: next, we outline the literature suggesting the role of learning orientation and environmental orientation in the context of SMEs, and internationalizing SMEs in particular. We then follow that with the two studies, one quantitative and one qualitative, where we examine the dynamics of learning and sustainability on SME internationalization in detail. We conclude by discussing the results and their implications on theory and practice of SME internationalization and growth.

\subsection{Learning orientation and SME internationalization}

Examining the role of learning in aiming for global entrepreneurial growth continues to be important, and this is due to several reasons. First, being able to learn is a pre-requisite of international growth in general (Johanson \&Wiedersheim-Paul 1977; Johanson \& Vahlne 1979) and a crucial way for an internationalizing enterprise to be able to overcome its liability of foreignness abroad in order to seize opportunities internationally and globally (Schwens \& 
Kabst, 2009). Second, learning and knowledge in general are major factors underlying entrepreneurial internationalization (see De Clercq et al., 2012).

Entering international markets can also increase technological learning and improve performance of SMEs in particular (Zahra et al., 2000). Having the organizational ability to learn may also lead to more rapid seizing of international and global opportunities and thus to increasing entrepreneurial growth: Rapidly internationalizing firms, defined sometimes as "born globals" (Rennie, 1993; Madsen \& Servais) in particular have been characterized as "aggressive learners" that seek experimentation and solutions as they arise (Jones et al. 2011).

Indeed, the pace of learning in internationalizing enterprises can vary (see Autio et al., 2000), and exposure to foreign markets itself can facilitate learning (Yeoh, 2004). The extent of effort placed in international learning can also result in higher performance of internationally and globally operating enterprises (De Clercq et al., 2016). Thus, it is critical that growth- and internationalization-seeking enterprises develop organizational cultures that help facilitate learning and thus making use of the accrued market and technological knowledge. Such a culture is captured by the extent of learning orientation exhibited by the enterprise.

Gatignon and Xuereb (1997, p. 78), argue that strategic orientations are "the strategic directions implemented by a firm to create the proper behaviors for the continuous superior performance of the business" whereas some other authors such as Noble et al. (2002) see them as more culturelike elements. We adhere to this latter view, and refer to learning orientation as the strategic orientation conceptualized as the organizational inclination for learning as strategic orientation embodied by the firm, in line with Sinkula et al. (1997), as well as with Baker and Sinkula (1999). The extent of learning orientation captures the shared vision, open-mindedness and commitment towards learning that the organization makes in developing its organizational culture (Baker \& Sinkula, 1999). In addition to these three areas, Calantone et al. (2002) have posited intra-organizational knowledge sharing.as a fourth dimension of learning orientation.

There are only a few studies (Kropp et al, 2006; Jantunen et al. 2008) that have included assessments of the impacts of learning orientation on international entrepreneurship. In their study, Kropp et al. (2006) found learning orientation to be one of the orientations determining performance of international entrepreneurial business ventures. However, their empirical context was limited to South Africa, and they remarked on the lack of studies examining learning orientation in the context of growth and international entrepreneurship, specifically calling for further research and confirmation of their initial study in the context of developed economies. Jantunen et al. (2008) then analyzed the impact of several strategic orientations on the performance of different types of internationalizing enterprises, finding that learning orientation 
predicted international performance of rapid internationalizers - born globals - in particular. However, for more traditional enterprise types their results were inconclusive.

In sum, then, while the extant literature on the impact of learning on entrepreneurial growth, and on the success of seizing opportunities abroad internationally and globally is ample, the concrete outcomes of having an organizational culture fostering knowledge absorption through learning is still somewhat lacking. However, based on the available evidence, we can expect that SMEs developing learning-oriented organizational cultures could reap benefits in more successful entry to international markets. Thus, we posit that:

- H1: The higher the learning orientation of an SME, the more likely it is to internationalize.

- H2: The higher the learning orientation of an internationalizing SME, the better its performance.

\subsection{Sustainability and Environmental Orientation in SME internationalization}

The concept of environmental orientation is intertwined with the closely related overlying concepts of sustainability and corporate social responsibility (CSR). Regarding the latter, some of the extant conceptualizations and operationalizations have distinguished a specific type of CSR - that of social and non-social of stakeholders (see Turker, 2009). However, this type of CSR may exist intertwined with a more general managerial orientation towards environmental thinking and sustainability: Menguc and Ozanne (2005) find that CSR and commitment to natural environment combine to form the concept of environmental orientation, which may have a positive impact on business performance in general.

Elsayed (2005) also examines environmental orientation, investigating the ways in which it affects environmental performance and responsiveness, but not business performance in general. Support for the intertwined ties is also provided in the literature review by Montiel (2008) which reveals that the research streams on CSR and sustainability are converging, with both streams increasingly focusing on similar environmental and social issues. This convergence reflects managerial reality, as in addition to protecting the interest of various stakeholders in an ethical manner, firms are also becoming increasingly challenged by the expectations of the stakeholders towards corporate environmentalism (Banerjee, 2002; Menguc and Ozanne, 2005).

In sum, then, extant research suggests that sustainability and corporate social responsibility can combine to form a distinct strategic orientation called environmental orientation. We further note that, while being socially and environmentally conscious from the corporate point of view can be a desirable end in itself, in order to qualify as a source of competitive advantage this orientation 
should also have a positive impact on market outcomes and performance of a given enterprise. Indeed, empirical support for the positive performance outcomes of environmental orientation have been found for example by Menguc and Ozanne (2005) who found that natural environmental orientation (composed of CSR, entrepreneurship and commitment to the natural environment) had a positive effect on profitability and market share of a firm.

Elsayed (2005) has further claimed that the size of a firm may influence the extent of its environmental orientation. Thus, the nature and dynamics of environmental orientation may be distinct for smaller entrepreneurial companies in particular. Moreover, the impact of environmental orientation on international growth and performance of these types of companies should be clarified, as extant research on international entrepreneurship has tended to neglect this aspect. Thus, in light of the extant literature suggesting that environmental orientation may have positive market and performance outcomes, for internationalizing enterprises in particular we posit that:

- H3: The higher the environmental orientation of an SME, the more likely it is to internationalize.

- H4: The higher the environmental orientation of an internationalizing SME, the better its performance.

The empirical context of our study is in the Finnish SMEs sector, which presents an interesting empirical venue for several reasons: First, SMEs have a particularly important role in Finland, as over $99 \%$ of Finnish enterprises fall within the SME definition and they act as major job creators driving the economy of the entire country (Lindholm et al., 2017). The economy overall is majorly export-driven, a phenomenon that, together with the prominence of SMEs, provides for a context where internationalizing SMEs are ample. Thus, we first apply regression modeling on data of Finnish SMEs collected in 2014 to confirm or reject the above hypotheses. As the results of this analysis turn out to be rather interesting and in need of further clarification, we then follow with a second empirical study, by examining a qualitative case of a Finnish SME operating in a sector where the role sustainability and environmental orientation are accentuated, namely the cleantech sector.

21.4 Empirical Study 1: The Impact of Learning Orientation and Environmental Orientation on Internationalization of SMEs.

\subsubsection{Data collection}

First, in order to test the impacts of learning and environmental orientation on international growth of SMEs, we collected data through an online survey. The data were collected via a webbased survey instrument between May 2014 and September 2014. In order to draw the initial 
sample of SMEs to be contacted, we used the Amadeus online database of Finnish SME-sized (10-250 employees) companies. The sample was a cross-industrial one including firms from several industries: we included forest industry, chemical industry, metal industry, other manufacturing activities and mining and quarrying, energy supply, water supply, waste management and construction. The average age of the drawn firms was 31 years and they employed on average 48 people.

As a result, we identified a total of 1130 firms to be contacted by phone. A total of 78 of them were judged as non-eligible, with the eligibility determined by the requirement that the respondents needed to have independency in terms of strategic decision-making. Because of this, for example sub-branches and Finnish subsidiaries of foreign firms were excluded from the study. Respondents were typically CEO's or other higher-level managers. 311 firms declined to participate in the study, most common reason being the lack of time. 306 firms were not reached regardless of several efforts. At the end, final responses were received from 148 firms, thus resulting in a $14 \%$ response rate $(148 / 1052)$.

\subsubsection{Measures}

We used a seven point Likert-scale ranging from "strongly disagree" to "strongly agree" for measuring the main independent variables of the study. For environmental orientation, five items describing responsibility to social and non-social stakeholders were adapted from Turker (2009) were combined with three self-developed items describing the importance of environmental thinking in the organization. We conducted principal component factor analysis using varimax rotation, an analysis that converged to a single factor capturing $62 \%$ of the total variation in the items. The communalities of the individual items varied between 0.48 and 0.73 , the KaiserMeyer-Olkin measure of sampling adequacy (KMO) value was 0.87, and Bartlett's test of sphericity significant $(\mathrm{p}<0.01)$. Conducting reliability analysis on the resulting items indicated that the resulting measure for learning orientation was acceptable (Cronbach's Alpha = 0.92). In line with Menguc and Ozanne (2005) we adhered to this factor as environmental orientation. The final items in the measure were as follows:

- We invest to create a better life for future generations.

- Our company implements special programs to minimize its negative impact on the natural environment.

- Our company targets a sustainable growth which considers to the future generations

- We pay much attention to the environmental hazards resulting from the manufacture of our products.

- We participate in activities whose goal is environmental protection.

- Production saving natural resources is a central goal of our business activities. 
- Preventing damage to nature is a central goal of our business activities.

- Our company contributes to the campaigns and projects that promote the well-being of the society.

Learning orientation was measured with a five-item scale adapted from Baker and Sinkula's 1999 study. Factor analysis converged as expected to a single factor capturing $77 \%$ of the total variance. Communalities of the individual items were acceptable, ranging from 0.71 to 0.84 , the Kaiser-Meyer-Olkin measure of sampling adequacy (KMO) value was 0.84, and Bartlett's test of sphericity significant $(\mathrm{p}<0.01)$. Conducting reliability analysis on the resulting items indicated that the resulting measure for learning orientation was acceptable (Cronbach's Alpha $=0.93$ ). The final items in the measure were as follows:

- The directors agree that the ability to learn is the core of our competitive advantage

- Our company's basic values include learning as a key factor of development

- The personnel's learning is seen in our company as an investment, not an expense

- Learning is seen as a key factor in regard to the survival of our company

- In our corporate culture, the employees' learning is seen as very important.

As part of the survey questionnaire, the respondents were asked if they have had international operations and from which year onwards. Those respondents that indicated such operations, we classified as international, and those who did not were classified as domestic SMEs. Consequently, we created a dichotomous variable consisting of these two types of SMEs to test for their propensity to internationalize. We then further examined the performance of the international part of this sample, through a market performance measure. This measure, consisting of a seven-point Likert scale, inquired upon the respondents to evaluate their performance in comparison to their main competitors in several central areas (acquisition of new customers, customer profitability, business profitability, turnover growth, market share and development of environmental-friendly products/services), from "performed very badly" to "performed very well". Finally, we controlled for firm age in our analysis, as the literature on entrepreneurial internationalization has indicated differences between early and late internationalization.

\subsubsection{Results}

The results of the binary logistic regression analysis for testing if the likelihood of the SMEs to have become international would be determined by their levels of learning orientation and environmental orientation are illustrated in table 2. In order to account for the possible independent effect of the age and size of the enterprise, we first proceeded with a model with the control variable only (table 2 , model 1 ). As the model was statistically non-significant (Chi- 
Square $=3.75, \mathrm{p}>0.05)$, and the coefficient of firm age was statistically non-significant $(\mathrm{B}=$ 0.02 , sig. $>0.05$ ), we deemed that the age of the firm did not crucially impact the propensity of SMEs to internationalize.

-Please insert Table 21.2 here-

When proceeding with the full model (table 2, model 2), the model turned statistically significant (Chi-square $=11.13, \mathrm{p}<0.01)$. The highly impactful factor determining the likelihood of the enterprises to internationalize was their extent of learning orientation $(B=0.57, p<0.01)$. Conversely, the level of environmental orientation did not predict internationalization propensity $(\mathrm{B}=-0.19, \mathrm{p}>0.05)$. In fact, as the coefficient itself was negative, having developed higher levels of environmental orientation were not beneficial to all in the sample firms having reached international markets. Thus, the conclusion was that learning orientation, rather than environmental orientation, was crucial for first foreign market entry among the enterprises.

Next, we assessed the impact of learning orientation and environmental orientation on the performance of internationally operating enterprises. The hypotheses were tested by using a linear hierarchical regression analysis. This analysis was again conducted in two stages in order to reveal the added variance explained by the independent variables over the control variables. The results, illustrated in table 3 , provided results contrary to the analysis on internationalization propensity above. As seen in table 3 (model 1), the control variable of firm age had a positive impact on performance $(\beta=0.23, \mathrm{p}<0.05)$, suggesting that older internationally operating companies had performed comparatively better than the more recent ones. This result was not surprising, considering that more established enterprises may have had more time in which to seize opening international and global opportunities. The model was also statistically significant $\left(\mathrm{F}=4.71\right.$, adjusted $\left.\mathrm{R}^{2}=0.04\right)$.

-Please insert Table 21.3 here-

The second step (table 3, model 2) included the central independent variables of learning orientation and environmental orientation. As seen in the table, the model remained statistically significant $(F=4.24, p<0.05)$, while the adjusted $R^{2}$ value rose to 0.10 . Of the two main dependent variables, environmental orientation was positive and statistically significant $(\beta=$ $0.22, \mathrm{p}<0.05)$, while learning orientation was not $(0.13, \mathrm{p}>0.05)$. We further checked for any issues of multicollinearity, by examining the values of the variable inflation factor (VIF) scores. They were all equal or less than 1.13, thus significantly lower than the suggested cut-off value of 10 by Hair et al. (1998).

Finally, as some studies have suggested interdependencies between strategic orientations in explaining performance (see Hakala, 2011), as a post-hoc analysis we tested for possible 
moderation and mediation effects. Starting with moderation, as seen in table 4, the analysis (model 1) testing for internationalization propensity was not statistically significant (Chi-Square $=9.67, \mathrm{p}>0.05)$ and the interaction variable itself was non-significant and neglible $(\mathrm{B}=0.01, \mathrm{p}$ $>0.05)$. Similarly, with the linear regression testing for the performance of the international SMEs (table 4, model 2), while the model as a whole was statistically significant $(\mathrm{F}=3.46, \mathrm{p}<$ $0.05)$, the interaction variable was again non-significant $(\beta=-0.11, p>0.05)$. Thus, no moderation effects linking learning and environmental orientation were found.

-Please insert Table 21.4 here-

We then concluded the statistical analysis with an examination of potential mediation effects. Specifically, extant research (Hakala, 2013) has suggested that learning orientation could act as a mediator between other strategic orientations and entrepreneurial growth. Thus, we tested for the possibility of similar effects through the four steps approach suggested by Baron and Kenny (1986) through Sobel's test (Sobel, 1982). However, while the regression models of the individual variables were within sufficient range, the resulting Sobel's test value was highly nonsignificant (0.52). Thus, learning orientation was found to not mediate a relationship between environmental orientation and performance.

Overall, from the results of this quantitative study, we found support for hypotheses H1 and H4, while no support was found for $\mathrm{H} 2$ and $\mathrm{H} 3$. Thus, we conclude that the impact of learning orientation and environmental orientation on internationalization of the SMEs was related to their stage of entrepreneurial growth: for those enterprises aiming to seize their first foreign opportunity and start operating abroad, accruing a learning oriented culture would be beneficial. Environmental orientation, on the other hand, would not facilitate such entry. However, as the company has managed to do so, the results suggest that long-term performance as an internationally operating enterprise may instead depend on specific environmental orientation, rather than being a learning-oriented enterprise in general. With the latter, our results confirm the findings of Hakala (2013), who also found learning orientation to not have an impact on entrepreneurial growth. However, that study did not assess the international dimension, and thus our results extend those findings to also account for performance and growth of internationalizing SMEs.

As noted by Gelbmann (2010), SMEs often find sustainable practices challenging, as adhering to such may require them to spend time and resources in trying to find ways in which to display such practices to their shareholders. We also further note that the nature of the industry sector itself may in part come to determine the requirements (and, by extension, the potential benefits) of environmental orientation and sustainable behavior of an SME. An example of such an industry sector is the cleantech sector, which in the Finnish context in particular is an emerging sector of industries supported institutionally and socially. 
There are various definitions of what can be understood as constituting "Cleantech", we are here adhering to the definition of Parker and O'Rourke (2006) of it as "any knowledge based product or service that improves operational performance, productivity or efficiency while reducing cost, inputs, energy consumption, waste or pollution". Thus, they are not limited to specific sectors of industry or technology, but have common which each other their aim to develop and do business with products and services aimed at decreasing the negative impact of human behavior on the environment. Therefore, an internationalizing SME operating in the cleantech sector provides a particularly fitting choice for a qualitative study through which to examine these results further. In doing so, we are following the advice of Siggelkow (2007), who advocated the investigation of such proverbial "talking pigs" through qualitative case research.

5 Empirical Study 2: Learning and Environmental Orientation in Internationalization of a Cleantech SME

Qualitative case study strategy is fitting for exploring the issues on learning and sustainability in the context of internationalizing SMEs further, as it allows a deep understanding of phenomena through the explanations and descriptions, as well as its phenomena's dynamics (Eisenhardt 1989). Consequently, we chose to examine a Finnish SME operating in the cleantech industry sector. In order to preserve confidentiality, we are referring to the enterprise as "Company Alpha".

\subsection{Case Description and Data Collection}

Alpha was founded in 2006 in Finland, where the product development and a production plant are still located. The main business of the company is manufacturing and designing the LED luminaires for street, sports, retail and industrial lighting. The company operates in the businessto-business sector, currently has turnover of ca. 5 million Euros, and is deriving ca. $10 \%$ of its turnover from abroad. Its internationalization activities are realized through distributors in seven countries in Europe and three in the Middle East / North Africa region. The descriptives of Alpha are listed in table 5 below.

-Please insert Table 21.5 here- 
The two top managers of the company Alpha - Sales and Marketing Director and International Sales Director - were interviewed separately by phone. Both interviewees have an extensive experience and knowledge of company's operations and hold the decision-making positions. Each of the interviews lasted for ca. 40 minutes, and the questions in the interview guide were developed in line with the results of the quantitative part of this study, from the literature on learning orientation, environmental orientation, and entrepreneurial internationalization. These interviews were semi-structured, meaning the interview questions follow the certain themes yet leave a possibility to ask additional questions for more comprehensive information obtaining and clarification, thus, the interviews were not identical. The data triangulation was achieved through the data being obtained from several sources such as company's website, websites of the related organizations, and news. The analysis of the data was performed from the transcriptions of the audiotaped interviews by attaining the answers to the themes of this research and then, writing up a case.

\subsection{Learning orientation of Alpha}

The Quality and Environmental (Q\&A) policy listed on the company website indicates that the smooth operations and commitment to the policy is possible "through regular reviews, internal audits and open discussion" pointing out towards the company's learning orientation. Correspondingly, the employees' learning consists from the quarter internal product trainings and annual external trainings for administrative staff that need to stay updated about the newest bookkeeping and other standards. In addition to that, the product trainings take place also for the international distributors to educate them about the product range. The shared vision is maintained by the disseminating the company strategy among the employees, updating on it at the meetings and following it.

The open-mindness of the employees is visible as they encouraged to freely suggest the changes and improvements to either company's products or processes. Then, written down these suggestions are discussed on the weekly product development meetings, and if approved, they are implemented. However, the product development is encouraged not only internally but the same procedure is applied when the initiative for the developments comes from the customers company's "the most important stakeholders" who through their suggestions influence the Alpha's business operations:

\footnotetext{
"If we get a good idea, I will make a report and the modification proposal, so this will be discussed, and then, depending on the difficulty and, let's say attractiveness of the proposal, how easy it's be doing, what kind of expectations would be on the effect side, we can be flexible." - Alpha International Sales Director
} 
The intraorganizational knowledge sharing takes place during the sales team meetings and international management team meetings held regularly, so the new internationally or locally gained knowledge disseminates widely:

"[Discussions are within] pretty much whole company. We are such a small team, so

there are no certain boundaries between different departments like in bigger enterprises"-Alpha International Sales Director

In sum, Alpha exhibits practices in line with a learning-oriented organization, across the conceptualization proposed originally by Baker and Sinkula (1999). As Alpha has started foreign operations not only regionally in Europe, but also extra-regionally in, for instance, the Middle Eastern region, we conclude that the results of this analysis further confirm those exhibited in the quantitative study above, namely that being able to absorb and utilize strategic and market knowledge systematically through learning-oriented practices within the enterprise is linked with a successful initial foreign market entry.

\subsection{Environmental Orientation of Alpha}

The Alpha's environmental policy is formulated along the quality policy at the company's website as a part of Q\&A policy. Among the company's claims, the quality-related issues are given the priority as they address the product safety, efficiency, reliability and customer service quality. The statements related to the environmental commitment are less emphasized and include products' environmental-friendliness through the long product lifecycle, minimization of harmful impact at the environment, and following the related legislation.

Alpha considers its contribution to the minimization of harmful impact at the environment through the saving of energy resources in the form of electricity consumption decrease, and recycling. The electricity savings by the production site, which has expanded by two times recently because of the new product group launch, are achieved through the change of lightning on site to the LED one - the product of the company.

The environmental orientation according to the interviewees is expressed through the "fulfilling all the requirements been set by laws and, other, regulations". This is reflected in the company complying with the ISO 14001/2015 standard which "specifies the requirements for an environmental management system that an organization can use to enhance its environmental performance" (ISO, 2017). The website press release about an obtaining of ISO certificate has a quote from the company's Managing Director who saw the standard as an instrument for the increase of employees' environmental awareness. Currently, environmental certification is a 
common feature in the lightning industry with most of the competitors having ISO 14001 or equivalent certification, while customers are demanding this certificate from Alpha.

Besides being in line with the formal documentation, Alpha is not active in any environmentally or socially-oriented activities beyond the actions required by regulations. Environmental values are not prioritized in the company's strategy, nor they are required from the distributors or suppliers. Rather, complying with the product quality standards is preferable:

"We are checking the suppliers and if they have the quality programme like ISO, so it's a good indication for us as a potential customer that at least they have working processes, and they are working, according to the responsible, more social responsible ways for corporate rules."

In sum, environmental values are not prioritized in the company's strategy, nor they are required from the distributors or suppliers. Rather, complying with the product quality standards is preferable:

"We are checking the suppliers and if they have the quality programme like ISO, so it's a good indication for us as a potential customer that at least they have working processes, and they are working, according to the responsible, more social responsible ways for corporate rules."

While fulfilling the communicated environmental promises, besides being in line with the formal documentation Alpha is not active in any environmentally or socially-oriented activities beyond the actions required by regulations.

\subsection{Internationalization of Alpha}

Alpha has exports and international operations started in 2010 are performed through the foreign distributors. The distributors are located in Sweden, Estonia, Lithuania, Benelux-countries, Germany and Switzerland, handle sales and maintain the contacts with customers and partners. The distributor network is in a dynamic state, thus, still listed on the website distributors in MENA region are currently not active, while the negotiations with the Norway distributors to start the partnership are underway.

The choice of international distributors happens during the thematic exhibitions and fairs, through the consultancy agents, personal networks of top management team and Chambers of Commerce. The main criteria for the distributors' choice from the Alpha's side are the experience in the field, market position and reputation. The environmental orientation of distributors is not a priority: 
"It's not in the validation process of us. It is, I think, mentally is quite important but I think it won't be the showstopper since we are not measuring them based on the ISO." - Alpha Sales and Marketing Director

In addition to finding the suitable distributor, the nature of the product requires that all necessary country- and industry-specific certificates and approvals are obtained before the start of exporting to the particular country. Thus, even within the European Union borders, the paperwork is a crucial part that precedes every new market entry while prolonging this process and imposing the additional costs for the company. On average, the new market entry process lasts for about one year from the initial interest in the market and finding the right partners to actual sales in this market.

\subsection{Summary of the Results of Study 2}

The case analysis overall suggests that Alpha is a company with a successful domestic operations and a broad reference list in Finland. It has the company learning practices aimed at the development of employees' knowledge and competences as well as to the smooth knowledge transfer flow within the company through the regular meetings and discussions. The initiatives and suggestions of the employees are encouraged and maintained properly when arise, altogether indicating the existence of learning orientation.

In addition, Alpha is fulfilling its environmental obligations those imposed externally by the regulations, standards and certifications, and internally by the company's Q\&A policy. However, the environmental orientation of the company does not go beyond the required actions and does not account the environment throughout the company's decisions and strategy as opposed to the product efficiency and quality which is the main priority.

Currently, achieving the growth is a main concern for the company being named among 60 the most fast growing Finnish companies in 2014 for a 3-year period 2010-2013. Particularly, once the growth at the Finnish market is no more a challenge, the top management is concerned with Alpha internationalization, particularly, the international growth. Thus, even the international performance has a positive trend in the recent years it is still constitute only $10 \%$ of company's turnover. The International Sales Director states that the growth of international sales is the main concern and the main focus of the Alpha's strategy while the Sales and Marketing Director confirms that:

"What comes to the export that's, I think, the big challenge. How to find the right partners, how to find the right areas or markets should it be joint ventures, should it 
be own resources, so forth. So a lot of questions." - Alpha Sales and Marketing

Director

\section{Discussion and Conclusion}

Environmental orientation of the firm in the triple-bottom-line approach is one of the keys to the sustainable firm's business in the long run (Elkington, 1994). Therefore, this study provides the empirical evidence on how the commitment to the environmental orientation influences the small firm's operations. Specifically, the results of quantitative study confirm that the company's orientation towards the integration of natural environmental concerns in their business operations contributes towards the overall business sustainability of the enterprise.

However, the following qualitative study then shows that even if the company operates in industries where "clean", "environmental", or "green" technologies are the main staple. industries which are in their essence are aimed at decreasing environmental harm, the nature of the industry itself does not necessary mean that the enterprise would incorporate environmental issues as a part of their decision-making. In other words, then, corporate environmentalism (Banerjee, 2002) is not by default engendered by the nature of the industry or the products, as even the international growth of an SME operating in the cleantech sector may by stymied by its lack of true environmentally conscious corporate culture - its lack of environmental orientation.

Moreover, even for the SMEs from such a specific industry, the compliance with the regulations defines the boundaries of its environmental responsibility as for the most of SMEs (Lynch-Wood and Williamson, 2013). Consequently, the adaptation of the voluntary environmental certifications such as the ISO 14001 does not in itself create environmental orientation in that company. Indeed, the firm is viewed environmentally oriented and committed only when the sustainable business activities are driven by the company's motivation and accountability for the company's environmental impact (Branzei and Vertinsky, 2002).

The results of the qualitative part of this research demonstrated that the environmental policy formulation in itself may not be sufficient for the success in international operations of an enterprise. Thus, according to the results, and supported by the quantitative empirical study, the international operations progress needs the complementation of the company's learning orientation practices with the environmentally oriented activities throughout the internationalization process. The lack of incorporation of the environmentally responsible practices and acting only within the required regulations and during the decision-making may not be enough if the enterprise is not able to also cultivate an environmentally conscious organizational culture within. 
We readily note several limitations of this study. One of those is naturally the single-country context: the level of home- and host-country institutional support and societal attitudes towards environmental sustainability tends to vary, and for both areas we consider Finland as a homecountry environment for SMEs to be both. It may be that less supporting home-country institutions, networks and other resources may impact the dynamics of environmental orientation and overall sustainability and social responsibility on entrepreneurial outcomes. Thus, we suggest that the impact of environmental orientation in particular be clarified through comparative studies accounting for such potential country-level differences. Similarly, we note that the empirical research setting did not make it possible to make long-term longitudinal analysis on how environmental orientation in internationalizing SMEs tends to develop, especially so as the examined case company was found to be deficient in this particular area. Thus, further clarification through longitudinal qualitative examination is called for.

However, in sum we see the results of this study as providing further illustration on the impact of strategic orientations and sustainable corporate culture on enterprise-level outcomes. This is one of the first studies linking environmental orientation to international entrepreneurship and thus, helps in opening up the discussion of these topics in more detail going forward. Managerially, this study also implicates several things. For one, entrepreneurs aiming to grow their enterprises through internationalization should pay attention to fostering the right kind of orientation depending on the stage of internationalization the company is engaged in and, particularly once an SME is operating in international markets, they should make sure that the culture of organizational learning extends into creation of environmentally conscious and socially responsible behavior. To do so is not only to "do the right thing"; indeed, doing so may also lead to a better performing enterprise. 


\section{References}

Autio, E., Sapienza, H.J. and Almeida, J.G., 2000. Effects of age at entry, knowledge intensity, and imitability on international growth. Academy of management journal, 43(5), pp.909-924.

Baker, W.E. and Sinkula, J.M., 1999. The synergistic effect of market orientation and learning orientation on organizational performance. Journal of the academy of marketing science, 27(4), pp.411-427.

Banerjee, S.B., 2002. Corporate environmentalism: The construct and its measurement. Journal of business research, 55(3), pp.177-191

Baron, R.M. and Kenny, D.A., 1986. The moderator-mediator variable distinction in social psychological research: Conceptual, strategic, and statistical considerations. Journal of personality and social psychology, 51(6), p.1173.

Branzei, O. and Vertinsky, I., 2002. Eco-sustainability orientation in China and Japan: Differences between proactive and reactive firms. Research in corporate sustainability: The evolving theory and practice of organizations in the natural environment, 85122.

Burpitt, W.J. and Rondinelli, D.A., 1998. Export decision-making in small firms: the role of organizational learning. Journal of World Business, 33(1), pp.51-68.

Calantone, R.J., Cavusgil, S.T. and Zhao, Y., 2002. Learning orientation, firm innovation capability, and firm performance. Industrial marketing management, 31(6), pp.515-524.

Cleantech Finland (2017). What's Cleantech Finland? [Online]. Available at:

http://www.cleantechfinland.com/en/web/cleantech/what-s-cleantech-finland [Accessed:

31.3.2017].

De Clercq, D., Sapienza, H.J., Yavuz, R.I. and Zhou, L., 2012. Learning and knowledge in early internationalization research: Past accomplishments and future directions. Journal of Business Venturing, 27(1), pp.143-165.

De Clercq, D., Zhou, L. and Wu, A., 2016. Unpacking the relationship between young ventures' international learning effort and performance in the context of an emerging economy. International Entrepreneurship and Management Journal, 12(1), pp.47-66.

Eisenhardt, K.M., 1989. Building theories from case study research. Academy of management review, 14(4), pp.532-550. 
Elkington, J., 1994. Towards the sustainable corporation: Win-win-win business strategies for sustainable development. California management review, 36(2), pp.90-100.

Elsayed, K. (2005). Reexamining the expected effect of available resources and firm size on firm environmental orientation: an empirical study of UK firms. Journal of Business Ethics, 65(3), 297-308.

Gatignon, H. and Xuereb, J.M., 1997. Strategic orientation of the firm and new product performance. Journal of marketing research, pp.77-90.

Gelbmann, U., 2010. Establishing strategic CSR in SMEs: an Austrian CSR quality seal to substantiate the strategic CSR performance. Sustainable Development, 18(2), pp.90-98.

Hair, J.F., Black, W.C., Babin, B.J., Anderson, R.E. and Tatham, R.L., 1998. Multivariate data analysis (Vol. 5, No. 3, pp. 207-219). Upper Saddle River, NJ: Prentice hall.

Hakala, H., 2011. Strategic orientations in management literature: three approaches to understanding the interaction between market, technology, entrepreneurial and learning orientations. International Journal of Management Reviews, 13(2), pp.199-217.

Hakala, H., 2013. Entrepreneurial and learning orientation: effects on growth and profitability in the software sector. Baltic Journal of Management, 8(1), pp.102-118.

ISO (2017). ISO 14001:2015. [Online]. Available at: https://www.iso.org/standard/60857.html [Accessed: 31.3.2017].

Jantunen, A., Nummela, N., Puumalainen, K. and Saarenketo, S., 2008. Strategic orientations of born globals-Do they really matter?. Journal of World Business, 43(2), pp.158-170.

Johanson, J. and Vahlne, J.E., 1977. The internationalization process of the firm-a model of knowledge development and increasing foreign market commitments. Journal of international business studies, pp.23-32. 
Johanson, J. and Vahlne, J.E., 1990. The mechanism of internationalisation. International marketing review, 7(4).

Johanson, J. and Wiedersheim-Paul, F., 1975. The internationalization of the firm-four Swedish cases. Journal of management studies, 12(3), pp.305-323.

Jones, M.V., Coviello, N. and Tang, Y.K., 2011. International entrepreneurship research (19892009): a domain ontology and thematic analysis. Journal of business venturing, 26(6), pp.632659.

Kachan \& Co. (2013). Cleantech redefined: Why the next wave of Cleantech infrastructure, technology and services will thrive in the twenty first century. www.petrofed.winwinhosting.net/newsletter/WR-335 15Nov13/w335 18.

Knight, G.A. and Cavusgil, S.T., 2004. Innovation, organizational capabilities, and the bornglobal firm. Journal of international business studies, 35(2), pp.124-141.

Kropp, F., Lindsay, N.J. and Shoham, A., 2006. Entrepreneurial, market, and learning orientations and international entrepreneurial business venture performance in South African firms. International Marketing Review, 23(5), pp.504-523.

Lindholm, T., P., Malinen \& Lemmelä, E. (2013). Pk-yritysbarometri - kevät 2017 (SMEBarometer - spring 2017), Vaasa, Finland: Suomen Yrittäjät Ry.

Lynch-Wood, G., \& Williamson, D. (2013). Understanding SME responses to environmental regulation. Journal of Environmental Planning and Management, 57(8), 1220-1239.

Madsen, T.K. and Servais, P., 1997. The internationalization of born globals: an evolutionary process?. International business review, 6(6), pp.561-583.

Menguc, B. and Ozanne, L.K., 2005. Challenges of the "green imperative": A natural resourcebased approach to the environmental orientation-business performance relationship. Journal of Business Research, 58(4), pp.430-438. 
Montiel, I., 2008. Corporate social responsibility and corporate sustainability: Separate pasts, common futures. Organization \& Environment, 21(3), pp.245-269.

Noble, C.H., Sinha, R.K. and Kumar, A., 2002. Market orientation and alternative strategic orientations: a longitudinal assessment of performance implications. Journal of marketing, 66(4), pp.25-39.

Parker, N., \& O'Rourke, A. (2006). New cleantech report: 700 investors can't be wrong. Venture Capital Journal, February, 45-46.

Pla-Barber, J., \& Alegre, J. (2014). The role of knowledge and learning in internationalization. International Business Review, 23(1), 1-3.

Rennie, M.W., 1993. Born global. The McKinsey Quarterly, (4), pp.45-53.

Schwens, C. and Kabst, R., 2009. How early opposed to late internationalizers learn:

Experience of others and paradigms of interpretation. International Business Review, 18(5), pp.509-522.

Siggelkow, N., 2007. Persuasion with case studies. The Academy of Management Journal, 50(1), pp.20-24.

Sinkula, J.M., Baker, W.E. and Noordewier, T., 1997. A framework for market-based organizational learning: Linking values, knowledge, and behavior. Journal of the academy of Marketing Science, 25(4), pp.305-318.

Sobel, M.E., 1982. Asymptotic confidence intervals for indirect effects in structural equation models. Sociological methodology, 13, pp.290-312.

Turker, D., 2009. How corporate social responsibility influences organizational commitment. Journal of Business Ethics, 89(2), pp.189-204. 
Yeoh, P.L., 2004. International learning: antecedents and performance implications among newly internationalizing companies in an exporting context. International Marketing Review, 21(4/5), pp.511-535.

Zahra, S.A., Ireland, R.D. and Hitt, M.A., 2000. International expansion by new venture firms: International diversity, mode of market entry, technological learning, and performance. Academy of Management journal, 43(5), pp.925-950. 


\section{Chapter 21}

\section{Sustainability and Knowledge Dynamics in Entrepreneurial Growth: Evidence from Internationalizing Finnish SMEs}

\section{Tables}

\section{Table 21.2 Results of testing for internationalization propensity.}

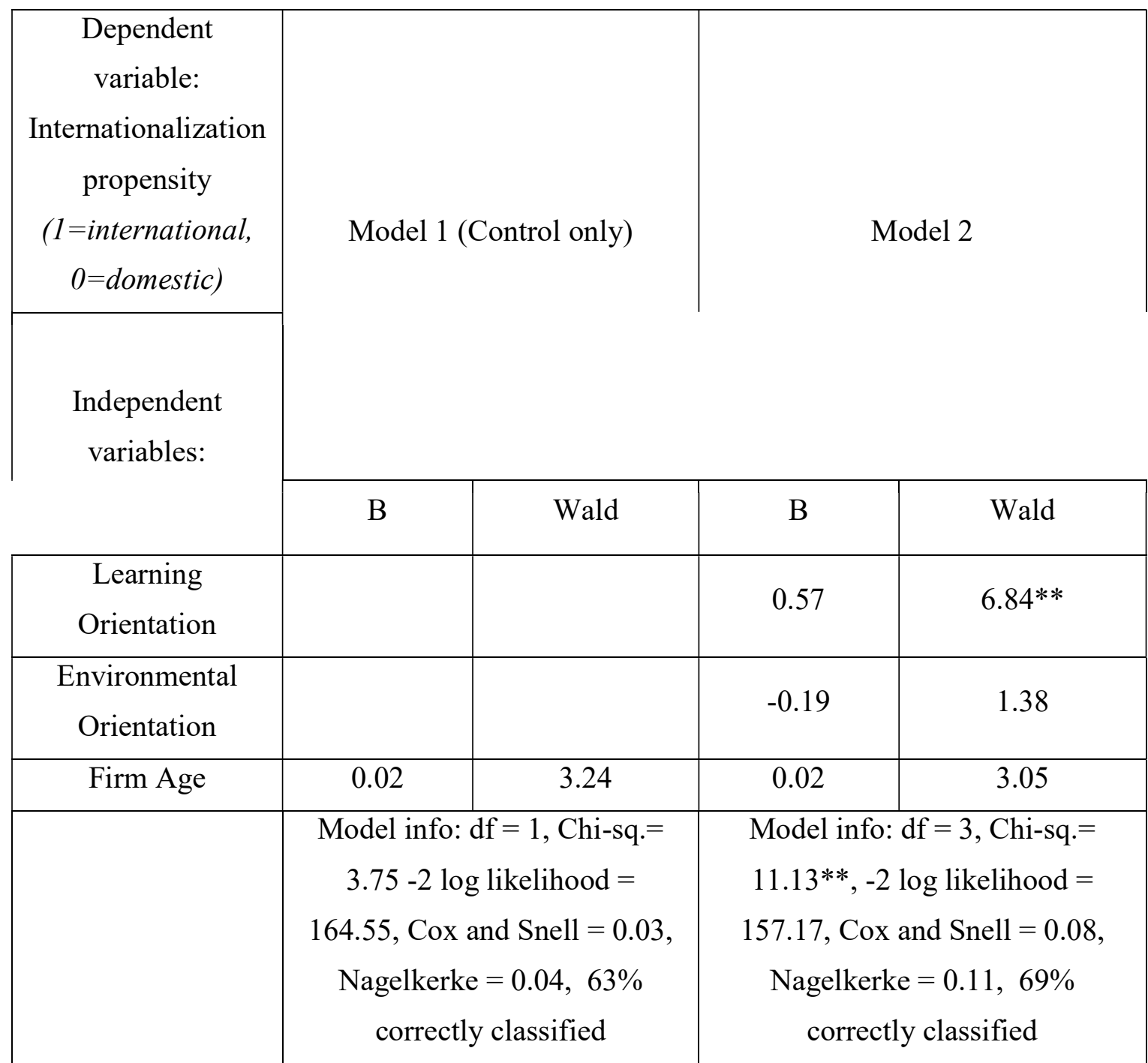

$$
\begin{gathered}
{ }^{*} \mathrm{p}<0.01 \\
* \mathrm{p}<0.05
\end{gathered}
$$


$\underline{\text { Table 21.3 Results for testing for performance of international SMEs. }}$

\begin{tabular}{|c|c|c|c|c|}
\hline $\begin{array}{c}\text { Dependent variable: } \\
\text { Performance }\end{array}$ & \multicolumn{2}{|c|}{$\begin{array}{c}\text { Model } 1 \\
\text { (control only) }\end{array}$} & \multicolumn{2}{|c|}{ Model 2} \\
\hline \multirow[t]{2}{*}{ Independent variables: } & & & & \\
\hline & $\beta$ & t-value & $\beta$ & t-value \\
\hline Learning Orientation & & & 0.13 & 1.16 \\
\hline Environmental Orientation & & & 0.22 & $2.00 *$ \\
\hline Firm Age & 0.23 & $2.17 *$ & 0.22 & $2.14^{*}$ \\
\hline $\operatorname{adj} . R^{2}$ & & 0.04 & & 0.10 \\
\hline $\mathrm{F}$ & & $4.71 *$ & & $4.24 * *$ \\
\hline
\end{tabular}

$$
* p<0.05
$$

Table 21.4 Results for testing for performance of international SMEs.

\begin{tabular}{|l|c|c|c|c|}
\hline \multirow{2}{*}{$\begin{array}{c}\text { Independent } \\
\text { variables: }\end{array}$} & \multicolumn{2}{|c|}{$\begin{array}{c}\text { Model 1 } \\
\text { (Propensity) }\end{array}$} & \multicolumn{2}{c|}{$\begin{array}{c}\text { Model 2 } \\
\text { (Performance) }\end{array}$} \\
\cline { 2 - 6 } & B & Wald & $\beta$ & t-value \\
\hline $\begin{array}{l}\text { Learning } \\
\text { Orientation }\end{array}$ & 0.44 & $5.02^{*}$ & 0.11 & 1.01 \\
\hline
\end{tabular}




\begin{tabular}{|c|c|c|c|c|}
\hline $\begin{array}{l}\text { Environmental } \\
\text { Orientation }\end{array}$ & -0.10 & 0.49 & 0.26 & $2.23 *$ \\
\hline $\begin{array}{l}\text { Interaction } \\
(\mathrm{LO} \times \mathrm{EO})\end{array}$ & 0.01 & 0.00 & -0.11 & -1.05 \\
\hline Firm Age & 0.01 & 2.52 & 0.22 & $2.09 *$ \\
\hline Model info: & \multicolumn{2}{|c|}{$\begin{array}{c}\mathrm{df}=4, \text { Chi-sq. }=9.67-2 \text { log likelihood }=177.05, \text { Cox } \\
\text { and Snell }=0.06, \text { Nagelkerke }=0.08,68 \% \text { correctly } \\
\text { classified }\end{array}$} & & \\
\hline $\operatorname{adj} . \mathrm{R}^{2}$ & & & & 0.11 \\
\hline $\mathrm{F}$ & & & & $3.46^{*}$ \\
\hline
\end{tabular}

$* p<0.05$ 
$\underline{\text { Table 21.5 Company Alpha descriptives. }}$

\begin{tabular}{|c|c|c|c|c|c|c|c|c|}
\hline Company & Established & 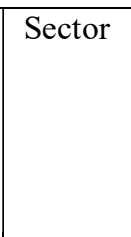 & $\begin{array}{c}\text { Number } \\
\text { of } \\
\text { employees }\end{array}$ & $\begin{array}{l}\text { Industry } \\
\text { (\% of } \\
\text { turnover, } \\
2017 \text { ) }\end{array}$ & $\begin{array}{l}\text { Cleantech } \\
\text { category }\end{array}$ & $\begin{array}{l}\text { Competitive } \\
\text { advantage }\end{array}$ & $\begin{array}{l}\text { Turnover in } \\
\text { euros (2015) }\end{array}$ & $\begin{array}{l}\text { Internation } \\
\text { alization }\end{array}$ \\
\hline Alpha & 2006 & $\begin{array}{c}\text { Business } \\
\text { to } \\
\text { business }\end{array}$ & 30 & $\begin{array}{c}\text { Energy } \\
\text { efficient } \\
\text { LED } \\
\text { luminaire } \\
\text { for street } \\
\text { and aerial } \\
\text { lighting } \\
(60 \%), \\
\text { industrial } \\
\text { lightning } \\
(20 \%) \text { and } \\
\text { lightning } \\
\text { of sport } \\
\text { facilities } \\
(20 \%) .\end{array}$ & $\begin{array}{c}\text { Energy } \\
\text { storage/Ef } \\
\text { ficiency }\end{array}$ & $\begin{array}{c}\text { Thermal } \\
\text { management, } \\
\text { design and } \\
\text { optical } \\
\text { performance }\end{array}$ & $5,000,000$ & $\begin{array}{l}\text { Distributor } \\
\text { s in } 7 \\
\text { European } \\
\text { and } 3 \\
\text { MENA } \\
\text { region } \\
\text { countries }\end{array}$ \\
\hline
\end{tabular}

\section{Figures}

There are no figures. 
Appendices

Table 21.1 Descriptives and intercorrelations of the variables used in the analysis.

\begin{tabular}{|l|l|l|l|l|l|l|l|}
\hline & Mean & $\begin{array}{l}\text { Std. } \\
\text { dev. }\end{array}$ & 1 & 2 & 3 & 4 & 5 \\
\hline 1 Learning orientation & 4.79 & 1.06 & 1 & & & & \\
\hline 2 Environmental orientation & 4.01 & 1.34 & $0.36^{* *}$ & 1 & & & \\
\hline 3 Firm Age [years] & 30.90 & 24.00 & 0.06 & 0.10 & 1 & & \\
\hline 4 Performance & 46.58 & 46.04 & $0.25^{* *}$ & $0.24^{* *}$ & 0.03 & 1 & \\
\hline $\begin{array}{l}\text { 5 Internationalization [0 } \\
\text { domestic, } 1=\text { international) }\end{array}$ & 4.84 & 1.08 & $0.21^{*}$ & 0.05 & $0.21^{*}$ & 0.00 & 1 \\
\hline
\end{tabular}

$* * \mathrm{p}<0.01$

$* \mathrm{p}<0.05$ 